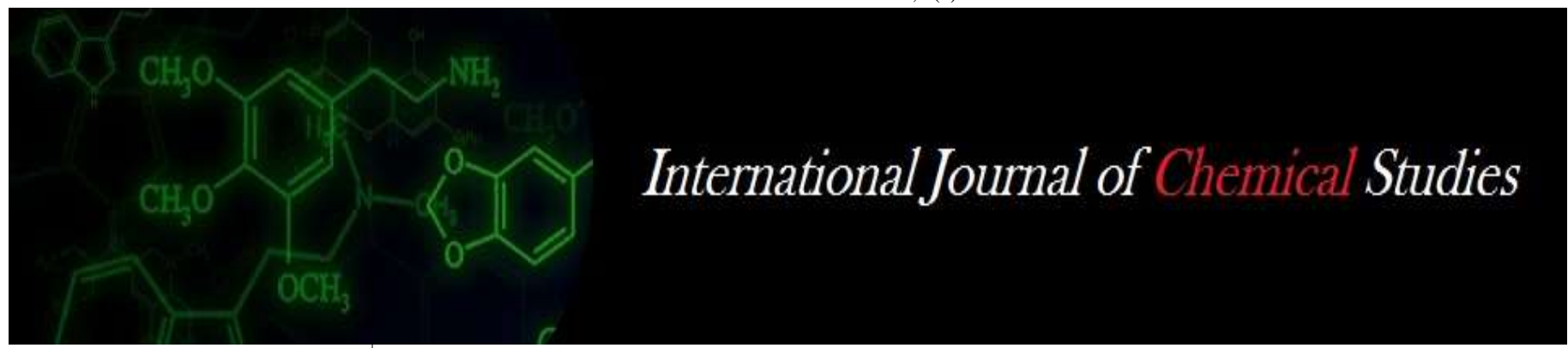

P-ISSN: 2349-8528

E-ISSN: 2321-4902

www.chemijournal.com

IJCS 2020; 8(6): 1867-1871

(C) 2020 IJCS

Received: 12-09-2020

Accepted: 02-11-2020

\section{UK Sawan}

Department of Plant Pathology, Dr. Balasaheb Sawant Konkan

Krishi Vidyapeeth, Dapoli,

Maharashtra, India

Joshi

Department of Plant Pathology,

Dr. Balasaheb Sawant Konkan

Krishi Vidyapeeth, Dapoli,

Maharashtra, India

\section{MJ Mane}

Department of Agronomy, Dr.

Balasaheb Sawant Konkan

Krishi Vidyapeeth, Dapoli,

Maharashtra, India

\section{PG Borkar}

Department of Plant Pathology, Dr. Balasaheb Sawant Konkan Krishi Vidyapeeth, Dapoli,

Maharashtra, India

\section{JS Dhekale}

Department of Agricultural Economics and Statistics, Dr. Balasaheb Sawant Konkan Krishi Vidyapeeth, Dapoli, Maharashtra, India

\section{Management of foot rot of finger millet (Eleusine coracana (L.) Gaertan) caused by Sclerotium rolfsii}

\author{
UK Sawant, MS Joshi, MJ Mane, PG Borkar and JS Dhekale
}

DOI: $\underline{\text { https://doi.org/10.22271/chemi.2020.v8.i6aa.11037 }}$

\begin{abstract}
Seed treatment with $T$. harzianum @ $5 \mathrm{~g} \mathrm{~kg}^{-1}$ seed followed by root dipping in $T$. harzianum solution plus application of Neem cake @ $50 \mathrm{~g} \mathrm{hill}^{-1}$ at transplanting recorded the lowest mean per cent disease incidence (3.69) and the maximum average yield for 2 years was $34.54 \mathrm{q} \mathrm{ha}^{-1}$. Seed treatment with thiram @ $3 \mathrm{~g} \mathrm{~kg}^{-1}$ of seed plus seedling root dipping in solution of T. harzianum at transplanting plus application of neem cake @ $50 \mathrm{~g} \mathrm{hill}^{-1}$ at transplanting was at par at $15 \mathrm{DAT}, 30 \mathrm{DAT}$ and 60 DAT respectively.
\end{abstract}

Keywords: Finger millet, foot rot, Sclerotium rolfsii, seed treatment, thiram, neem cake powder, root diping, trichoderma harzianum, percent disease incidence (PDI)

\section{Introduction}

Finger millet (Eleusine coracana (L.) Gaertan) is one of the important cereal millet crops grown under rain fed condition by small and marginal farmers and tribal population for both grain and forage. It is commonly called as 'nutritious millet' providing fair amount of proteins, minerals, calcium, fibres and vitamins in abundance to people. It is good source for growing infants and aged people who need calcium supplement. The higher fiber content of finger millet helps in many ways as it prevents constipation, high cholesterol formation and intestinal cancer. People suffering from diabetes are advised to eat finger millet and other small millets instead of rice (Malleshi and Haddimani 1993) ${ }^{[8]}$.

$S$. rolfsi is predominantly distributed in tropical and sub-tropical countries. It is cultivated in more than 25 countries in Africa and Asia, because of its adaptability to different agro climatic conditions. In India major finger millet growing states are Karnataka, Tamil Nadu, Andhra Pradesh, Odisha, Maharashtra, Uttar Pradesh, Bihar and Gujrat accounting for more than 95.00 per cent of the total finger millet production (Sonnad, 2005) ${ }^{[15]}$. It is grown on 1268 thousand hectares with a production of 1888.5 thousand ton. In Maharashtra, finger millet occupies an area of about 927 hundred ha with an annual grain production of 1111 hundred ton with productivity $1198 \mathrm{~kg} \mathrm{ha}^{-1}$. The largest acreage of ragi is in Konkan region. In Konkan region, finger millet plays an important role in agriculture with an area of 326 hundred ha with an annual production 411 hundred ton (Anonymous, 2016) ${ }^{[2]}$.

Foot rot of finger millet caused by $S$. Rolfsi Sacc. is common in rainy season when warm temperature and high relative humidity exists. Weber $(1931)^{[16]}$ and Garret (1956) ${ }^{[6]}$ reported that fungus survived in the soil for many years by producing sclerotial bodies and causing the disease either in the form of stem rot or foot rot or root rot in addition to leaf blight on several of its hosts. S.rolfsii can over winter as mycelium in infected tissues or plant debris. Sclerotia serves as the principal over wintering structure and primary inoculum for disease persisting near the soil surface.

Foot rot which has been reported to cause more than 50 per cent yield loss. As the disease was minor and sporadic in nature, extensive systematic studies have not been carried out, but it is increasing in the recent past; particularly under in high rainfall situations (Nagaraja and Reddy, $2009)^{[11]}$. The present research work was conducted to investigate the combinations of various treatments including chemicals, bio-agents and organic amemdments to manage the disease to minimum level and to obtain the maximum yield.

\section{UK Sawant}

Department of Plant Pathology, Dr. Balasaheb Sawant Konkan Krishi Vidyapeeth, Dapoli, Maharashtra, India 
Materials and Methods

Preparation of nursery (Raising of seedlings) and preparation of experimental plot

Nursery for raising seedlings was prepared as per treatments $\mathrm{T}_{1}$ (Seed treatment with Thiram @ $3 \mathrm{~g} \mathrm{~kg}^{-1}$ of seed), $\mathrm{T}_{2}$ (Seed treatment with Trichoderma harzianum@ $5 \mathrm{~g} \mathrm{~kg}^{-1}$ of seed) and $\mathrm{T}_{3}$ (Control) by using standard practices. Preparation of experimental plot was also done by employing all standard agronomic techniques.

Treatment details for the management of foot rot of finger millet.

\begin{tabular}{|c|c|c|}
\hline Tr. No. & Treatment & Time of application \\
\hline $\mathrm{T}_{1}$ & Seed treatment with thiram @ $3 \mathrm{~g} \mathrm{~kg}^{-1}$ of seed. & Sowing \\
\hline $\mathrm{T}_{2}$ & Seed treatment with Trichoderma harzianum@ $5 \mathrm{~g} \mathrm{~kg}^{-1}$ of seed. & sowing \\
\hline $\mathrm{T}_{3}$ & $\begin{array}{c}\text { Seed treatment with thiram@ } 3 \mathrm{~g} \mathrm{~kg}^{-1} \text { of seed. + seedling root dipping in water solution of T.harzianum } 0.5 \% \\
\text { before transplanting. }\end{array}$ & Sowing and transplanting \\
\hline $\mathrm{T}_{4}$ & $\begin{array}{l}\text { Seed treatment with T.harzianum @ 5 } \mathrm{g} \mathrm{kg}^{-1} \text { of seed + seedling root dipping in T.harzianum before } \\
\text { transplanting. }\end{array}$ & Sowing and transplanting \\
\hline $\mathrm{T}_{5}$ & Seed treatment with thiram @ $3 \mathrm{~g} \mathrm{~kg}^{-1}$ of seed + application of Neem cake @ $50 \mathrm{~g}$ hill ${ }^{-1}$ during transplanting. & Sowing and transplanting \\
\hline $\mathrm{T}_{6}$ & $\begin{array}{l}\text { Seed treatment with T.harzianum @ } 5 \mathrm{~g} \mathrm{~kg}^{-1} \text { of seed + application of Neem cake @ } 50 \mathrm{~g} \mathrm{hill}^{-1} \text { during } \\
\text { transplanting. }\end{array}$ & Sowing and transplanting \\
\hline $\mathrm{T}_{7}$ & $\begin{array}{l}\text { Seed treatment with thiram @ } 3 \mathrm{~g} \mathrm{~kg}^{-1} \text { of seed + seedling root dipping in T.harzianum before transplanting + } \\
\text { application of Neem cake @ } 50 \mathrm{~g} \mathrm{hill}{ }^{-1} \text { during transplanting. }\end{array}$ & Sowing and transplanting \\
\hline $\mathrm{T}_{8}$ & $\begin{array}{l}\text { Seed treatment with T.harzianum @ } 5 \mathrm{~g} \mathrm{~kg}^{-1} \text { of seed }+ \text { seedling root dipping in T.harzianum before } \\
\text { transplanting + application of Neem cake @ } 50 \mathrm{~g} \text { hill }{ }^{-1} \text { during transplanting. }\end{array}$ & Sowing and transplanting \\
\hline $\mathrm{T}_{9}$ & Control & $\begin{array}{ll}---- \\
-1\end{array}$ \\
\hline
\end{tabular}

\section{Methods of recording observations}

Data were recorded visually by observing the symptoms. The observations were recorded at fortnight interval from the day of transplanting. The number of foot rot infected plants were counted from each treatment plot and the percent disease incidence was worked out by the formula

$$
\text { Percent Disease Incidence (PDI) }=\frac{\text { Number of foot rot infected plants }}{\text { Total no of plants observed }} \times 100
$$

\section{Percent Disease Control (PDC) against untreated was calculated by the formula}

$$
\% \text { Disease Control }(\mathrm{PDC})=\frac{\mathrm{PDI} \text { in control-PDI in treatment }}{\mathrm{PDI} \text { in control }} \times 100
$$

\section{Yield}

Fingers were harvested at maturity and yields of net plot were recorded in $\mathrm{kg}$ per plot and later expressed in quintols per hectare.

\section{Percent yield increase over control}

$$
\text { Yield increase over control }(\%)=\frac{\text { Yield in treatment plot-Yield in control plot }}{\text { Yield in control plot }} \times 100
$$

\section{Results and Discussion}

\section{Percent disease incidence}

The pooled analysis of data depicted in Table 1 and Fig.1 revealed that the per cent disease incidence (PDI) ranged from 0.19 to 5.05 at 15 DAT, 0.85 to 7.45 at 30 DAT, 2.18 to 12.13 at $45 \mathrm{DAT}$ and 3.69 to 13.41 at 60 DAT respectively. Seed treatment with $T$. harzianum @ $5 \mathrm{~g} \mathrm{~kg}^{-1}$ seed plus root dipping in $T$. harzianum solution plus application of neem cake @ 50 $\mathrm{g}$ hill $^{-1}$ at transplanting $\left(\mathrm{T}_{8}\right)$ recorded the lowest per cent disease incidence $0.19,0.85,2.18$ and 3.69 at 15 DAT, 30DAT, 45 DAT and 60 DAT respectively. and the highest per cent disease incidence 5.05, 7.45, 12.13 and 13.41 was recorded in $\mathrm{T}_{9}$ (Control) at $15 \mathrm{DAT}, 30 \mathrm{DAT}, 45 \mathrm{DAT}$ and 60 DAT respectively.

Seed treatment with $T$. harzianum @ $5 \mathrm{~g} \mathrm{~kg}^{-1}$ seed plus seedling root dipping in $T$. harzianum solution plus application of Neem cake @ $50 \mathrm{~g} \mathrm{hill}^{-1}$ at transplanting $\left(\mathrm{T}_{8}\right)$ and Seed treatment with thiram @ $3 \mathrm{~g} \mathrm{~kg}^{-1}$ of seed plus seedling root dipping in solution of $T$. harzianum at transplanting plus application of neem cake @ $50 \mathrm{~g} \mathrm{hill}^{-1}$ at transplanting $\left(\mathrm{T}_{7}\right)$ were at par at $15 \mathrm{DAT}, 30 \mathrm{DAT}$ and 60 DAT. Seed treatment with T. harzianum @ $5 \mathrm{~g} \mathrm{~kg}^{-1}$ of seed + application of neem cake @ $50 \mathrm{~g} \mathrm{hill}^{-1}$ at transplanting $\left(\mathrm{T}_{6}\right)$ and seed treatment with thiram@3 $\mathrm{g} \mathrm{kg}^{-1}$ of seed plus application of neem cake @ $50 \mathrm{~g} \mathrm{hill}^{-1}$ at transplanting $\left(\mathrm{T}_{5}\right)$ were at par at 15 DAT and 30 DAT. Seed treatment with $T$. harzianum @ $5 \mathrm{~g} \mathrm{~kg}^{-1}$ of seed plus seedling root dipping in solution of $T$. harzianum at transplanting $\left(\mathrm{T}_{4}\right)$ and seed treatment with thiram @ $3 \mathrm{~g} \mathrm{~kg}^{-1}$ of seed plus seedling root dipping in solution of $T$. harzianum at transplanting $\left(\mathrm{T}_{3}\right)$ were at par at 30 DAT and seed treatment with thiram @ $3 \mathrm{~g} \mathrm{~kg}^{-1}$ of seed plus application of neem cake @ $50 \mathrm{~g} \mathrm{hill}^{-1}$ at transplanting $\left(\mathrm{T}_{5}\right)$ and Seed treatment with T. harzianum @ 5 $\mathrm{g} \mathrm{kg}^{-1}$ of seed + Seedling root dipping in solution of $T$. harzianum at transplanting $\left(\mathrm{T}_{4}\right)$ and Seed treatment with Thiram @ $3 \mathrm{~g} \mathrm{~kg}^{-1}$ of seed + Seedling root dipping in solution of $T$. harzianum at transplanting $\left(\mathrm{T}_{3}\right)$ were at par at $45 \mathrm{DAT}$. In respect of terminal disease incidence at $60 \mathrm{DAT}$, seed treatment with T. harzianum @ $5 \mathrm{gm} \mathrm{kg}^{-1}$ seed plus seedling root dipping in $T$. harzianum solution plus application of Neem cake@ @ $50 \mathrm{~g} \mathrm{hill}^{-1}$ at transplanting $\left(\mathrm{T}_{8}\right)$ and Seed treatment with Thiram @ $3 \mathrm{~g} \mathrm{~kg}^{-1}$ of seed + Seedling root dipping in solution of $T$. harzianum at transplanting + Application of Neem cake @ $50 \mathrm{~g} \mathrm{hill}^{-1}$ at transplanting $\left(\mathrm{T}_{7}\right)$ were at par. So also treatments Seed treatment with Thiram @ $3 \mathrm{~g} \mathrm{~kg}^{-1}$ of seed + Seedling root dipping in solution of $T$. harzianum at transplanting $\left(\mathrm{T}_{3}\right)$ and seed treatment with $T$. harzianum @ $5 \mathrm{~g} \mathrm{~kg}^{-1}$ of seed $\left(\mathrm{T}_{2}\right)$ were at par.

\section{Per cent disease reduction}

The comparison of all the treatments comprising use of bioagents, organic and fungicides with control revealed that seed treatment with $T$. harzianum @ $5 \mathrm{~g} \mathrm{~kg}^{-1}$ seed plus root dipping in $T$. harzianum solution plus application of neem cake @ 50 $\mathrm{g} \mathrm{hill}{ }^{-1}$ at transplanting $\left(\mathrm{T}_{8}\right)$ recorded the highest $(72.46 \%)$ reduction in disease incidence which was followed by seed treatment with thiram @ $3 \mathrm{~g} \mathrm{~kg}^{-1}$ of seed + seedling root dipping in solution of $T$. harzianum at transplanting + application of neem cake @ $50 \mathrm{~g} \mathrm{hill}^{-1}$ at transplanting $\left(\mathrm{T}_{7}\right)$, Seed treatment with $T$. harzianum @ $5 \mathrm{~g} \mathrm{~kg}^{-1}$ of seed + 
application of neem cake @ $50 \mathrm{~g} \mathrm{hill}^{-1}$ at transplanting $\left(\mathrm{T}_{6}\right)$. More than 50 per cent reduction in disease was recorded in seed treatment with $T$. harzianum @ $5 \mathrm{~g} \mathrm{~kg}^{-1}$ seed plus seedling root dipping in $T$. harzianum solution plus application of neem cake @ $50 \mathrm{~g} \mathrm{hill}^{-1}$ at transplanting $\left(\mathrm{T}_{8}\right)$ $(72.46 \%)$ and seed treatment with thiram @ 3 $\mathrm{g} \mathrm{kg}^{-1}$ of seed + Seedling root dipping in solution of $T$. harzianum at transplanting + application of neem cake @ $50 \mathrm{~g} \mathrm{hill}^{-1}$ at transplanting $\left(\mathrm{T}_{7}\right)(67.42)$.

Mundhe (2005) ${ }^{[9]}$ tested ten antagonists against $S$. rolfsi, the causal agent of finger millet foot rot. They found that maximum inhibition of $S$. rolfsi was accomplished due to $T$. harzianum (strain P) (73.77\%) followed by T. harzianum (strain JCR) $(73.00 \%)$ T. viride (JCR) $(72.66 \%)$ and $P$. fluorescens $(71.55 \%)$. The result of thiarm applications are in agreement with the results of Dabre (2000) who found the total inhibition of $S$. rolfsii causing collar rot of gerbera due to Thiram $(0.25 \%)$. The results of application of $T$. harzianum to the root zone of tomatoes controlled Sclerotium rolfsii infection in naturally infested soil and further on transplanting the treated plants showed reduced disease incidence to the tune of 93 per cent (Elad et al., 1980) ${ }^{[5]}$. Furrow application of talc based $T$. harzianum (106 cfu g-1) @ $1.5 \mathrm{~kg}$ mixed with $300 \mathrm{~kg}$ of either farm yard manure or castor cake ha ${ }^{-1}$ just before sowing to control stem rot disease of groundnut was recommended for Saurashtra farmers (Anon., 2001) ${ }^{[1]}$. The findings of application of combination of bio-agent and fungicides are in tune with research work of Dutta and Das (2002) ${ }^{[4]}$ who tested the efficacy of $T$. harzianum, $T$. viride, and $T$. koningii and two seed dressing fungicides viz. thiram $(0.10 \%)$ and mancozeb $(0.10 \%)$ for the management of collar rot of tomato, caused by $S$. rolfsii. Soil application of Trichoderma at the time of transplanting or application of farmyard manure with $T$. harzianum resulted in minimum disease incidence and increased dry mass of roots, shoots and yield. Results of using different Trichoderma antagonists for complete growth inhibition of $S$. rolfsii causing stem rot of groundnut (Sahu and Senapati, 2003 and Rao and Kulkarni,
2003) ${ }^{[14,13]}$ also justified the present findings. The results obtained by use of soil organic amendment like neem cake tally with findings of Johnson et al. (2003) ${ }^{[7]}$ who conducted a field experiment for four years using different soil amendments (neem cake, gypsum, single super phosphate, pongamia cake, castor cake and farmyard manure) in management of $S$. rolfsii inciting stem rot of groundnut. Among the different amendments, basal application of gypsum at $500 \mathrm{~kg} \mathrm{ha}^{-1}$ followed by neem cake at $150 \mathrm{~kg} \mathrm{ha}^{-1}$ reduced the stem rot incidence by 39 and $31 \%$ respectively resulting in additional pod yield of 260 and $200 \mathrm{~kg} \mathrm{ha}^{-1}$, respectively. Pawar (2013) [12] conducted integrated management study on the foot rot disease of finger millet in field condition with 7 different treatments. Among these, seed treatment with $P$. flourescens and T. viride each @ $5 \mathrm{~g} / \mathrm{kg}$ showed least per cent disease incidence (12.38\%).

\section{Effect on yield}

The maximum average yield of 2 years was $34.54 \mathrm{q} \mathrm{ha}^{-1}$ in the treatment seed treatment with T.harzianum @ $5 \mathrm{~g} \mathrm{~kg}^{-1}$ seed plus seedling root dipping in $T$. harzianum solution plus application of Neem cake @ 50g hill ${ }^{-1}$ at transplanting $\left(\mathrm{T}_{8}\right)$. It was followed by Seed treatment with Thiram @ $3 \mathrm{~g} \mathrm{~kg}^{-1}$ of seed + Seedling root dipping in solution of $T$. harzianum at transplanting + Application of Neem cake @ $50 \mathrm{~g} \mathrm{hill}^{-1}$ at transplanting $\left(\mathrm{T}_{7}\right)$ which recorded yield of $31.46 \mathrm{q} \mathrm{ha}^{-1}$. Average yield of treatment of Seed treatment with Trichoderma harzianum @ $5 \mathrm{~g} \mathrm{~kg}^{-1}$ of seed + Application of Neem cake@ $0 \mathrm{~g} \mathrm{hill}^{-1}$ at transplanting $\left(\mathrm{T}_{6}\right)$ and Seed treatment with Thiram @ 3 $\mathrm{g} \mathrm{kg}^{-1}$ of seed + Application of Neem cake @ $50 \mathrm{~g} \mathrm{hill}^{-1}$ at transplanting $\left(\mathrm{T}_{5}\right)$ for 2 consecutive Kharif seasons was $30.52 \mathrm{q} \mathrm{ha}^{-1}$ and $30.08 \mathrm{q}^{-}$ ${ }^{1}$ and were statistically at par. Maximum average per cent increase in yield (37.42\%) as compared to control was recorded in treatment of Seed treatment with T. harzianum @ $5 \mathrm{~g} \mathrm{~kg}^{-1}$ seed plus seedling root dipping in $T$. harzianum solution plus application of Neem cake @ $50 \mathrm{~g} \mathrm{hill}^{-1}$ at transplanting $\left(\mathrm{T}_{8}\right)$.

Table 1: Management of foot rot of finger millet

\begin{tabular}{|c|c|c|c|c|c|c|}
\hline \multirow{2}{*}{$\begin{array}{l}\text { Tr. } \\
\text { No. }\end{array}$} & \multirow{2}{*}{ Treatment } & \multicolumn{4}{|c|}{ Per cent Disease Incidence* } & \multirow{2}{*}{$\begin{array}{l}\text { Per cent disease } \\
\text { reduction compared to } \\
\text { untreated }\end{array}$} \\
\hline & & 15 DAT & 30 DAT & 45 DAT & 60 DAT & \\
\hline $\mathrm{T}_{1}$ & Seed treatment with Thiram @ $3 \mathrm{~g} \mathrm{~kg}^{-1}$ of seed. & $\begin{array}{c}3.23 \\
(10.35)\end{array}$ & \begin{tabular}{c|c|}
4.54 \\
$(12.30)$
\end{tabular} & $\begin{array}{c}8.00 \\
(16.42)\end{array}$ & $\begin{array}{c}9.90 \\
(18.33)\end{array}$ & 26.14 \\
\hline$T_{2}$ & Seed treatment with Trichoderma harzianum @ $5 \mathrm{~g} \mathrm{~kg}^{-1}$ of seed & $\begin{array}{l}2.46 \\
(9.02)\end{array}$ & $\begin{array}{c}3.95 \\
(11.46)\end{array}$ & $\begin{array}{c}7.31 \\
(15.68)\end{array}$ & $\begin{array}{c}9.23 \\
(17.68)\end{array}$ & 31.13 \\
\hline $\mathrm{T}_{3}$ & $\begin{array}{c}\text { Seed treatment with Thiram @ } 3 \mathrm{~g} \mathrm{~kg}^{-1} \text { of seed.+Seedling root dipping } \\
\text { in solution of } T \text {. harzianum at transplanting }\end{array}$ & $\begin{array}{c}2.00 \\
(8.13)\end{array}$ & $\begin{array}{c}3.21 \\
(10.32)\end{array}$ & \begin{tabular}{c|c}
6.64 \\
$(14.93)$
\end{tabular} & $\begin{array}{c}8.82 \\
(17.27)\end{array}$ & 34.19 \\
\hline $\mathrm{T}_{4}$ & $\begin{array}{l}\text { Seed treatment with T. harzianum @ } 5 \mathrm{~g} \mathrm{~kg}^{-1} \text { of seed + Seedling root } \\
\text { dipping in solution of } T \text {. harzianum at transplanting }\end{array}$ & $\begin{array}{l}1.28 \\
(6.49)\end{array}$ & $\begin{array}{c}3.15 \\
(10.22)\end{array}$ & $\begin{array}{c}6.49 \\
(14.75)\end{array}$ & $\begin{array}{c}8.23 \\
(16.67)\end{array}$ & 38.64 \\
\hline $\mathrm{T}_{5}$ & $\begin{array}{c}\text { Seed treatment with Thiram @ 3 } \mathrm{g} \mathrm{kg}^{-1} \text { of seed + application of Neem } \\
\text { cake @ } 50 \mathrm{~g} \mathrm{hill}{ }^{-1} \text { at transplanting }\end{array}$ & $\begin{array}{c}0.89 \\
(5.41)\end{array}$ & $\begin{array}{c}2.00 \\
(8.13)\end{array}$ & \begin{tabular}{c|}
6.29 \\
$(14.52)$
\end{tabular} & $\begin{array}{c}7.59 \\
(15.99)\end{array}$ & 43.38 \\
\hline $\mathrm{T}_{6}$ & $\begin{array}{c}\text { Seed treatment with } T \text {. harzianum @ } @ \mathrm{~g} \mathrm{~kg}^{-1} \text { of seed + Application of } \\
\text { Neem cake @ } 50 \mathrm{~g} \mathrm{hill}{ }^{-1} \text { at transplanting }\end{array}$ & $\begin{array}{c}0.81 \\
(5.16)\end{array}$ & $\begin{array}{c}1.69 \\
(7.46)\end{array}$ & \begin{tabular}{c|c|}
4.57 \\
$(12.34)$
\end{tabular} & $\begin{array}{c}7.05 \\
(15.39)\end{array}$ & 47.41 \\
\hline $\mathrm{T}_{7}$ & $\begin{array}{c}\text { Seed treatment with Thiram @ } 3 \mathrm{~g} \mathrm{~kg}^{-1} \text { of seed + Seedling root dipping } \\
\text { in solution of } T . \text { harzianum }+ \text { Application of Neem cake @ } 50 \mathrm{~g} \mathrm{hill}^{-1} \\
\text { at transplanting }\end{array}$ & $\begin{array}{c}0.39 \\
(3.58)\end{array}$ & $\begin{array}{c}1.28 \\
(6.49)\end{array}$ & $\begin{array}{c}3.06 \\
(10.07)\end{array}$ & $\begin{array}{c}4.12 \\
(11.71)\end{array}$ & 67.42 \\
\hline $\mathrm{T}_{8}$ & $\begin{array}{c}\text { Seed treatment with } T \text {. harzianum @ } 5 \mathrm{~g} \mathrm{~kg}^{-1} \text { of seed + Seedling root } \\
\text { dipping in solution of } T \text {. harzianum + Application of Neem cake @ } 50 \\
\mathrm{~g} \mathrm{hill}{ }^{-1} \text { at transplanting at transplanting }\end{array}$ & $\begin{array}{c}0.19 \\
(2.49)\end{array}$ & $\begin{array}{c}0.85 \\
(5.28)\end{array}$ & $\begin{array}{c}2.18 \\
(8.49)\end{array}$ & $\begin{array}{c}3.69 \\
(11.07)\end{array}$ & 72.46 \\
\hline $\mathrm{T}_{9}$ & Control & $\begin{array}{c}5.05 \\
(12.98)\end{array}$ & $\begin{array}{c}7.45 \\
(15.83)\end{array}$ & \begin{tabular}{c|c}
12.13 \\
$(20.38)$
\end{tabular} & $\begin{array}{c}13.41 \\
(21.48)\end{array}$ & - \\
\hline & S. Em \pm & 0.09 & 0.16 & 0.20 & 0.16 & - \\
\hline & C. D (at $5 \%)$ & 0.28 & 0.50 & 0.61 & 0.48 & - \\
\hline
\end{tabular}


Table 2: Effect of management of foot rot on yield of finger millet $\mathrm{C} v$ - Dapoli 2

\begin{tabular}{|c|c|c|c|}
\hline Tr. No. & Treatment & *Yield (kg/ha) & \% increase Over control \\
\hline $\mathrm{T}_{1}$ & Seed treatment with Thiram @ $3 \mathrm{~g} \mathrm{~kg}^{-1}$ of seed. & 2779.33 & 10.56 \\
\hline $\mathrm{T}_{2}$ & Seed treatment with $T$. harzianum @ $5 \mathrm{~g} \mathrm{~kg}^{-1}$ of seed & 2829.33 & 12.55 \\
\hline $\mathrm{T}_{3}$ & $\begin{array}{c}\text { Seed treatment with Thiram @ } 3 \mathrm{~g} \mathrm{~kg}^{-1} \text { of seed.+ Seedling root dipping in solution of } T \text {. } \\
\text { harzianum at transplanting }\end{array}$ & 2900.33 & 15.38 \\
\hline $\mathrm{T}_{4}$ & $\begin{array}{c}\text { Seed treatment with } T \text {. harzianum @ } 5 \mathrm{~g} \mathrm{~kg}^{-1} \text { of seed + Seedling root dipping in solution of } \\
\text { T. harzianum at transplanting }\end{array}$ & 2952.16 & 17.44 \\
\hline $\mathrm{T}_{5}$ & $\begin{array}{c}\text { Seed treatment with Thiram @ } 3 \mathrm{~g} \mathrm{~kg}^{-1} \text { of seed + application of Neem cake @ } 50 \mathrm{~g} \mathrm{hill}{ }^{-1} \text { at } \\
\text { transplanting }\end{array}$ & 3008.50 & 19.68 \\
\hline $\mathrm{T}_{6}$ & $\begin{array}{c}\text { Seed treatment with } T \text {. harzianum @ } 9 \mathrm{~g} \mathrm{~kg}^{-1} \text { of seed + Application of Neem cake @ } 50 \mathrm{~g} \\
\text { hill }^{-1} \text { at transplanting }\end{array}$ & 3052.33 & 21.42 \\
\hline $\mathrm{T}_{7}$ & $\begin{array}{c}\text { Seed treatment with Thiram @ 3 } \mathrm{g} \mathrm{kg}^{-1} \text { of seed + Seedling root dipping in solution of } T \text {. } \\
\text { harzianum + Application of Neem cake @ 50 g hill-1 at transplanting }\end{array}$ & 3146 & 25.15 \\
\hline $\mathrm{T}_{8}$ & $\begin{array}{c}\text { Seed treatment with } T \text {. harzianum @ } 5 \mathrm{~g} \mathrm{~kg}^{-1} \text { of seed + Seedling root dipping in solution of } \\
\text { T. harzianum + Application of Neem cake @ } 50 \mathrm{~g} \mathrm{hill}{ }^{-1} \text { at transplanting }\end{array}$ & 3454.33 & 37.42 \\
\hline \multirow[t]{3}{*}{$\mathrm{T}_{9}$} & Control & 2513.66 & - \\
\hline & S.Em \pm & 14.87 & - \\
\hline & C.D $(\mathrm{P}=0.05)$ & 44.59 & - \\
\hline
\end{tabular}

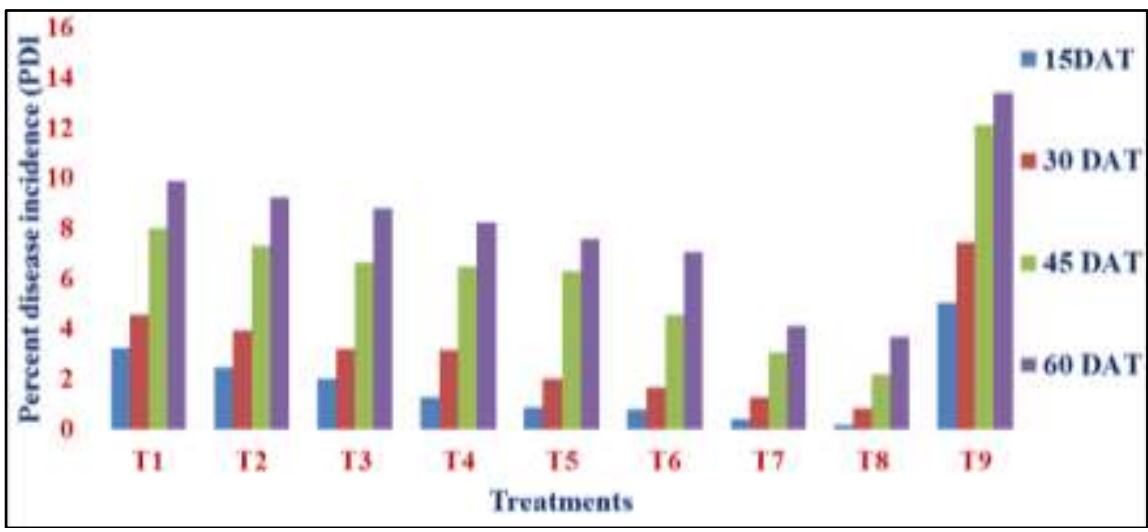

Fig 1: Percent disease incidence of finger millet foot rot

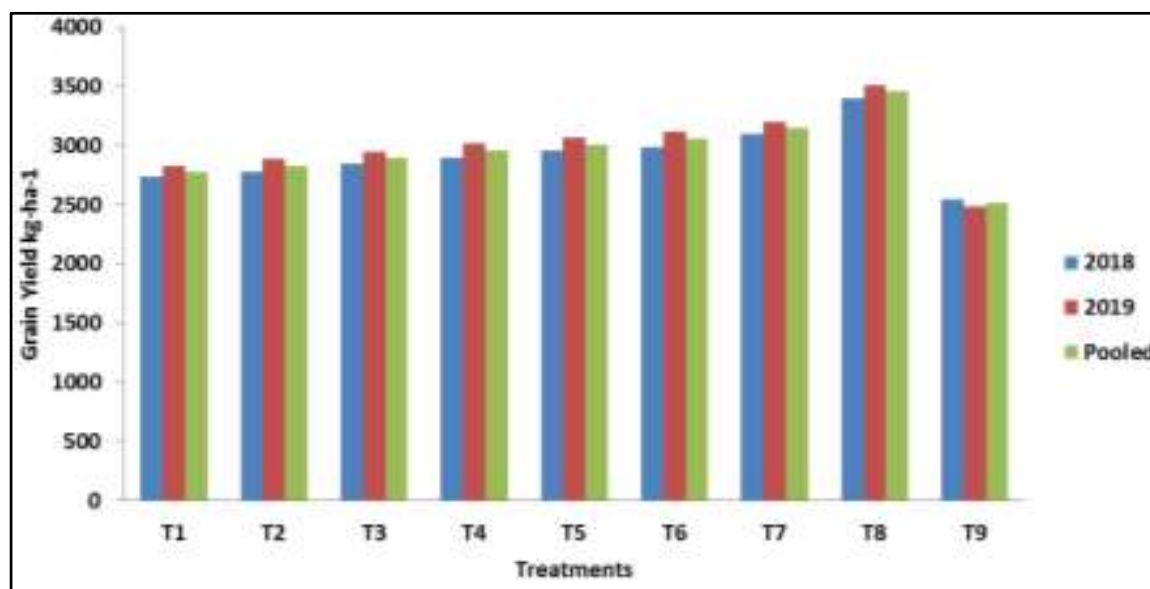

Fig 2: Effect of management on grain yield of Finger Millet Kharif 2018, Kharif 2019 and Pooled

\section{Conclusion}

On the basis of this study it is concluded that the Seed treatment with T. harzianum @ $5 \mathrm{gm} \mathrm{kg}^{-1}$ seed plus root dipping in $T$. harzianum solution plus application of Neem cake @ $50 \mathrm{~g} \mathrm{hill}^{-1}$ at transplanting recorded minimum foot rot severity (3.69) with the highest $(72.46 \%)$ reduction in disease incidence. Maximum average yield (34.54 $\left.\mathrm{q} \mathrm{ha}^{-1}\right)$ was also recorded in the same treatment.

\section{Acknowledgement}

The authors acknowledge the help provided by Department of Plant Pathology and Department of Agronomy, College of Agriculture, Dapoli, Dr.Balasaheb Sawant Konkan Krishi
Vidyapeeth, Dapoli.for providing farm facilities to conduct the field research trial.

\section{References}

1. Anonymous. Biological control of stem/pod rot (Sclerotium rolfsii) of groundnut. Proceeding of 36th Meeting of Plant Protection Sub Committee of GAU Research Council, 2001, 5.

2. Anonymous. Disrict-wise estimated area, production and yield of ragi (Small millet) in Konkan division of Maharashtra. Support Team. Districtsofindia.com, 2016. 
3. Dabre SG. Studies on collar rot (Sclerotium rolfsii Sacc.) of gerbera (Gerbera jamesonii Hook). M.Sc.(Ag.) thesis submitted to the M.P.K.V., Rahuri (M.S.), India 2000.

4. Dutta P, Das BC. Management of Collar rot ofTomato by Trichoderma spp. and chemicals. Indian Phytopath 2002;55(2):235-237.

5. Elad Y, Chet I, Katan J. Trichoderma harzianum, a biological agent effective against Sclerotium rolfsii and Rhizoctoniasolani. Phytopathology 1980;70:119-121.

6. Garret SD. Biology of root infecting fungi. Cambridge University Press, 1956, 293.

7. Johnson M, Subramanyam K, Balaguravaiah D, Sudheer MJ. Management of stem rot in groundnut through soil amendments. Annal Pl. Prot. Sci 2003;11(1):83-85.

8. Malleshi NG, Haddimani NA. Nutritional and technological characteristics of small millets and preparation of value added products from them. In: Advances in small millet proceedings of second International small millet workshop, Bulawayo, Zimbabwe, 1993.

9. Mundhe VG. Studies on foot rot of Nagli (Eleusinecoracona L) and its management. M. Sc. (Ag.) thesis submitted to Department of Plant Pathology, College of Agriculture, Dapoli, 2005.

10. Nikam PS. Investigation of early blight of tomato caused by Alternaria solani(Elli and martin) jones and Grout. PhD Thes. VNMKV Parbhani, Maharashtra, 2013.

11. Nagraja A, Reddy B. Foot rot of Finger millet-an increasing disease problem in Karnataka. Crop Res 2009;38(2):224-225.

12. Pawar DM. Management of foot rot (Sclerotium rolfsii Sacc.) of finger millet (Eleusine coracana L. Gaertn) Ph.D. thesis submitted to Department of Plant Pathology, N. M. College of Agriculture, Navsari Agricultural University, Navsari, Gujrat, India, 2013.

13. Rao SN, Kulkarni S. Effect of Trichoderma spp. on thegrowth of $\mathrm{S}$. rolfsii Sacc. J Biological Control 2003;17(2):181-184.

14. Sahu KC, Senapati AK. Efficacy of Trichoderma spp. against Sclerotium rolfsii causing stem rot of groundnut. J Appl. Biol. 2003;13(1/2):38-40.

15. Sonnad SK. Stability analysis in white ragi (Eleusine coracann Gaertn) genotypes. M.Sc. (Ag.) thesis submitted to University of Agricultural Sciences, Dharwad, 2005.

16. Weber GF. Blights of carrot caused by Sclerotium rolfsi with geographic distribution and host range of the fungi. Phytopathology 1931;21:103-109. 